\title{
Modeling of seizure transitions with ion concentration dynamics
}

\author{
Damiano Gentiletti ${ }^{1 *}$, Marco De Curtis ${ }^{2}$, Vadym Gnatkovski ${ }^{2}$, Piotr Suffczynski ${ }^{1}$ \\ From 24th Annual Computational Neuroscience Meeting: CNS*2015 \\ Prague, Czech Republic. 18-23 July 2015
}

Traditionally it is considered that neuronal synchronization in epilepsy is caused by a chain reaction of synaptic excitation. However, it has been shown that synaptic transmission is not necessary for epileptiform synchronization [1]. In order to investigate the respective roles of synaptic and non-synaptic neuronal coupling in seizure transitions, we developed a computational model of hippocampal network, involving extracellular space, realistic dynamics of $\mathrm{Na}^{+}, \mathrm{K}^{+}$and $\mathrm{Cl}^{-}$ions, the glial uptake and diffusion mechanism. We show that network behavior under synaptic coupling conditions may be quite different from the neurons' activities when specific non-synaptic components are included. In particular, we show that in the extended model, strong discharge of inhibitory interneurons may result in long lasting accumulation of extracellular $\mathrm{K}^{+}$, which sustains depolarization of principal cells and causes their pathological discharges. This effect is not present in a reduced, purely synaptic network. These results confirm the experimental hypothesis that increase of inhibitory interneurons firing may lead to increased firing in the pyramidal cells through accumulation of extracellular potassium [2]. The model also shows that all potassium clearance mechanisms (glial uptake, sodium-potassium pump, potassium diffusion) are critically important to reproduce the experimental findings. This means that computational modeling of seizure activity without ion dynamics may lead to unrealistic results.

\section{Authors' details}

'Department of Experimental Physics, University of Warsaw, Warsaw, Poland. ${ }^{2}$ Fondazione Istituto Neurologico Carlo Besta, Milan, Italy.

Published: 18 December 2015

\footnotetext{
* Correspondence: gentiletti.damiano@gmail.com

'Department of Experimental Physics, University of Warsaw, Warsaw, Poland Full list of author information is available at the end of the article
}

References

1. Jefferys JGR, Haas HL: Synchronized bursting of CA1 hippocampal pyramidal cells in the absence of synaptic transmission. Nature 1982, 300:448-450.

2. De Curtis M, Gnatkovsky V: Reevaluating the mechanisms of focal ictogenesis: the role of low-voltage fast activity. Epilepsia 2009, 50(12):2514-2525.

doi:10.1186/1471-2202-16-S1-P242

Cite this article as: Gentiletti et al:: Modeling of seizure transitions with ion concentration dynamics. BMC Neuroscience 2015 16(Suppl 1):P242.

Submit your next manuscript to BioMed Central and take full advantage of:

- Convenient online submission

- Thorough peer review

- No space constraints or color figure charges

- Immediate publication on acceptance

- Inclusion in PubMed, CAS, Scopus and Google Scholar

- Research which is freely available for redistribution

Submit your manuscript at www.biomedcentral.com/submit
() Biomed Central
C Biomed Central

(c) 2015 Gentiletti et al. This is an Open Access article distributed under the terms of the Creative Commons Attribution License (http:// c) 2015 Gentiletti et al. This is an Open Access article distributed under the terms of the Creative Commons Attribution License (http://
creativecommons.org/licenses/by/4.0), which permits unrestricted use, distribution, and reproduction in any medium, provided the original work is properly cited. The Creative Commons Public Domain Dedication waiver (http://creativecommons.org/publicdomain/ zero/1.0/) applies to the data made available in this article, unless otherwise stated. 